
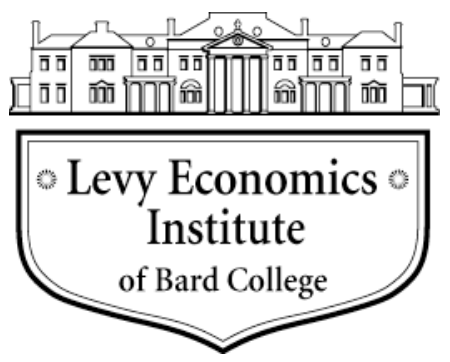

Working Paper No. 884

\title{
Gendered Patterns of Time Use over the Life Cycle: Evidence from Turkey
}

by

\author{
Ebru Kongar and Emel Memiş* \\ Levy Economics Institute of Bard College
}

February 2017

\begin{abstract}
* We acknowledge with gratitude the constructive feedback we received from Günseli Berik, Rachel Connelly, Mark Price, and Şemsa Özar on earlier versions of this study.
\end{abstract}

The Levy Economics Institute Working Paper Collection presents research in progress by Levy Institute scholars and conference participants. The purpose of the series is to disseminate ideas to and elicit comments from academics and professionals.

Levy Economics Institute of Bard College, founded in 1986, is a nonprofit, nonpartisan, independently funded research organization devoted to public service. Through scholarship and economic research it generates viable, effective public policy responses to important economic problems that profoundly affect the quality of life in the United States and abroad.

Levy Economics Institute P.O. Box 5000

Annandale-on-Hudson, NY 12504-5000 http://www.levyinstitute.org

Copyright (C) Levy Economics Institute 2017 All rights reserved 


\begin{abstract}
Using data from the 2006 Turkish Time-Use Survey, we examine gender differences in time allocation among married heterosexual couples over the life cycle. While we find large discrepancies in the gender division of both paid and unpaid work at each life stage, the gender gap in paid and unpaid work is largest among parents of infants compared to parents of older children and couples without children. The gender gap narrows as children grow up and parents age. Married women's housework time remains relatively unchanged across their life cycle, while older men spend more time doing housework than their younger counterparts. Over the course of the life cycle, women's total work burden increases relative to men's. Placing our findings within the gendered institutional context in Turkey, we argue that gender-inequitable work-family reconciliation policies that are based on gendered assumptions of women's role as caregivers exacerbate gender disparities in time use.
\end{abstract}

Keywords: Economics of Gender; Time Use; Life Cycle; Turkey

JEL Classifications: D13, J16, J22 


\section{INTRODUCTION}

With only 31.5 percent of women in the labor force compared to 71.6 percent of men, Turkey has one of the largest gender gaps in labor force participation globally (Turkish Statistical Institute [TSI] 2016a). Despite being one of the most industrialized countries in the Middle East and North Africa (MENA) region, the female labor force participation rate in Turkey actually declined by about 3 percentage points between 1988 and 2015 (OECD 2016). This decline is in sharp contrast to the increase in women's labor force participation that accompanied industrialization in many countries in the global South since the late 1970s. Moreover, of employed women, 28.4 percent are unpaid family workers, mainly in agriculture, compared to only 4.7 percent of employed men (TSI 2016a).

Feminist scholars who investigate these gender disparities in Turkey's labor markets identify the persistence of patriarchal norms and traditional gender roles as an important determinant of women's "non-participation” in the labor market (Özar and Günlük-Şenesen 1998). Women's role as wives and mothers has been institutionalized within the macroeconomic policy and societal context in the post-1980 period, and has been increasingly emphasized by the religious conservatist party, which has been in power since the early 2000s (Illkkaracan 2012).

Married women and mothers are considerably less likely to be in the labor force than their single and childless counterparts, while the opposite holds for married men and fathers (Dayığlu and Kurdar 2010). Within the household, it is well known that while men take on the breadwinner role, women shoulder the bulk of the housework and care work. However, a more exact examination of the gender division of unpaid labor and how it varies across key stages of the life cycle had not been possible until the release of the first nationally representative time-use survey data in 2006. In this study, using data from this dataset, we explore the gender disparities in paid work (market labor), unpaid work (family labor), and leisure among married and cohabiting couples over their life course. The life cycle approach allows us to analyze the gender division of paid and unpaid labor across a series of socially defined events (e.g., parenthood) and roles (e.g., wife/husband, mother/father) over time. Our methodology is similar to that employed by Anxo et al. (2011) who explore the gender disparities in time use across the life cycle in France, Italy, Sweden, and the 
US from a comparative perspective. Their study contributes to our understanding of how the societal and institutional context, welfare regime, and gender norms affect gender disparities in time use. Our study aims to contribute to the literature on gendered patterns of time use from a life-course perspective by providing evidence from Turkey. In the rest of this study, we first present a brief overview of the institutional context in Turkey with a focus on the gendered welfare regime and the rise of the religious conservatist party since 2002 . We then review the relevant gender and time use literature and introduce the empirical framework for our analysis. Our main findings show large gender disparities in time use at each life stage. As expected, parenthood exacerbates these inequalities. While we do not conduct an explicit cross-country analysis, our findings show notable differences in gendered patterns of time use across the life cycle in Turkey compared to previous findings in the literature for Italy, Sweden, France, and the US. However, cross-country similarities emerge as well, particularly between Italy, the US, and Turkey, pointing to shared challenges regarding gender equity in time use in different institutional contexts.

\section{INSTITUTIONAL CONTEXT IN TURKEY: AN OVERVIEW}

In a recent email exchange, Şemsa Özar coined the term "corporatist-neoliberal a la Turca" to describe the welfare regime in Turkey, a description we find very accurate (Ş. Özar, personal communication, August 25, 2016). It is corporatist in Esping-Anderson's (1990: 112) sense as it is shaped by the "church" and influenced by a strong commitment to the preservation of traditional family values. ${ }^{1}$ It is neoliberal in the sense that after the 1980 military coup, the state facilitated trade and capital liberalization, deregulation of economic activity, and privatization of state-owned enterprises. The industrialization strategy shifted away from import-substitution to exportorientation, and the post-1980 period has been characterized by erosion of the redistributive welfare state and cuts in public spending. In the 1990s and 2000s, the structural adjustment programs

\footnotetext{
${ }^{1}$ Esping-Anderson's (1990) welfare state typology that categorizes 18 countries of the Organisation of Economic Cooperation and Development (OECD) into three ideal welfare regimes of liberal, conservative (corporatiststatist/corporativist), and social democratic. The key distinction between these three regimes is the relative roles of the state, the family, and the market in welfare provisioning. Since its publication, his welfare system has been widely criticized and modified, including by feminist scholars, who have incorporated the gender division of paid and unpaid labor into the typology (Orloff 1993; Özar and Yakut-Cakar 2013).
} 
implemented as a result of International Monetary Fund (IMF) agreements further facilitated privatization and cuts in public spending. The "a la Turca" part points out the differences between the Turkish welfare regime and the southern European type, especially in the post-1980 period. The similarities between the two regimes include centrality of the family in the welfare regime and a highly fragmented and hierarchical corporatist system of health and pension benefits to formally employed heads of household (Buğra and Keyder 2006). However, as argued by Buğra and YakutCakar (2010), the patterns of social policy and female employment in Turkey and in the southern European welfare regimes diverged in the post-1980 period as the southern European welfare regimes, but not Turkey, prioritized social inclusion and reduction of inequalities, reflecting the influence of the European Union. The reforms in Turkey, on the other hand, reflected the influence of the IMF and the World Bank within the context of continued neoliberal economic restructuring (Buğra and Yakut-Cakar 2010). For instance, microfinance, a policy instrument preferred by these international institutions, is emphasized as the key to poverty reduction without challenging the broader inequalities in gender relations or ideologies (Benería 1999; Moghadam 1998a). More recently, the Justice and Development Party (Adalet ve Kalkinma Partisi in Turkish, AKP hereafter), a party that self-identifies as moderate Islamist and has been in power since the general elections in 2002, has advocated for microfinance as the key to poverty reduction, along with mobilization of charitable contributions by "good Muslims," which are directed to the poor through municipalities that act as "brokers in charity" (Buğra and Keyder 2006: 224). Under the rule of AKP, other social assistance policies, such as increased public expenditure on health and education, have been formulated in terms of social aid (Öniş 2012).

The neoliberal macroeconomic context in the post- 1980 period and the welfare regime outlined above are gendered and have gendered outcomes. For instance, some studies find a positive relationship between the shift to export orientation and female share in employment in manufacturing; however, this was primarily through the use of flexible labor, and married women and mothers were more likely to have found employment in the informal sector working from home through subcontracting arrangements (Berik and Cagatay 1990; Ozar and Gunluk- Senesen 1998; Ozler 2000). Moreover, women's share in total employment declined, as the growth of female employment in manufacturing was not large enough to offset the decline in women's share in agricultural employment (İlkkaracan 2012). 
Since 2002, the AKP government has emphasized family as the pillar of the welfare regime, and their policies reflect the centrality of the family in welfare provision. President Recep Tayyip Erdoğan, the founder of AKP, has frequently stressed the role of women as mothers, most recently in 2016 , as he declared, '[a] woman who refuses motherhood by saying, 'I work,' is, in fact, denying her womanhood" (Tuysuz 2016). Work-family reconciliation policies that we discuss below reflect this traditional view of gender roles, which discourage women from entering paid employment. On the other hand, social security benefits are limited to those in formal employment, therefore they primarily go to men, given that less than half of women workers are engaged in formal employment in Turkey. Women workers who are unpaid family workers or are employed without being registered with any social security institution are either excluded by this system or are eligible for social security only as dependents of their male relatives (İlkkaracan 2012; Özar and Yakut-Çakar 2013).

As emphasized by Orloff (1993: 322), analysis of a welfare regime through a feminist lens requires examination of the social organization of caring and domestic labor and gender differences in access to paid work, primarily whether, and the extent to which, married women and mothers are assured employment. For mothers, work-family reconciliation policies - in particular, public provision of affordable and quality childcare services, access to paid parental leave, and flexible working hours - are likely to increase labor force participation and attachment. These policies also foster gender equality in the division of paid and unpaid work. On the other hand, gender asymmetries in these policies (for instance, parental leave just for mothers, not for fathers) are built on patriarchal and heteronormative assumptions about women's role as caregivers and exacerbate gender inequalities in paid and unpaid work. Paid maternity/parental leave policies in Turkey are gender asymmetric. Specifically, women in formal employment are entitled to 16 weeks of paid maternity leave and an additional 72 weeks of unpaid leave, while prior to 2015 revisions to labor law, there was no parental leave and only public employees were entitled to 10 days of paid and 24 months of unpaid paternity leave (Turkish Labor Law 2013a). ${ }^{2}$ Another problem pointed out in the feminist economic literature with the paid maternity leave policy in Turkey is that it covers only women in formal employment, who, as mentioned earlier,

\footnotetext{
${ }^{3}$ In 2015, fathers of newborn children became entitled to 5 days of paid paternity leave, adoptive parents became entitled to 3 days of paid leave, and parents of disabled or chronically ill children became entitled to 10 days of paid leave.
} 
constitute less than half of the female workforce in Turkey (İlkkaracan 2012; Özar and YakutCakar 2013).

Like the maternity/parental leave policy, childcare policy in Turkey is consistent with the emphasis on the role of women as mothers. Specifically, the only public provision of childcare services for children under the age of six is for five-year olds and only since 2006, when public schools started kindergarten classes for children between the ages of five and six (Illkkaracan 2012). Only a few other policies, all of which target employed mothers, aim to address the workfamily conflict. First, according to Turkish labor law, a nursing female employee is entitled to one-and-a-half hours per workday to breastfeed her child under the age of one (Turkish Labor Law 2013b). Secondly, in the private sector, workplaces with 100-150 female employees are required to have a nursing room within close proximity to the workplace (Turkish Labor Law 2013b). And finally, workplaces with more than 150 female employees are required to provide a childcare center (Turkish Labor Law 2013b). However, these workplace regulations are not enforced, therefore it is not surprising that only 21 percent of the 100 largest employers in Turkey provided some form of childcare facilities in 2009 (Zahidi and Ibarra 2010). Consequently, only a small number of families benefit from childcare centers provided by the employer, and according to a 2013 Hacettepe University Institute of Population Studies (HUIPS) survey, about 40 percent of employed women with at least one child under the age of six rely on the unpaid work of female relatives (mother-in-law, mother, female children) for primary care of their child(ren) while they are at work - a number relatively unchanged since the previous survey conducted in 2008 (HUIPS 2013: 183; HUIPS 2008: 119). About 30 percent of employed women take their child(ren) to work with them, while only 11.9 percent of women in 2008 and 20.9 percent in 2013 used some form of childcare service (HUIPS 2008 and 2013). 
Not surprisingly, the share of mothers who use childcare services increases considerably with household wealth: one-third of mothers in the wealthiest 20 percent of households in 2008 and 43 percent in 2013 used some form of childcare services, compared to about only 1 percent of mothers in households at the bottom 20 percent of the wealth distribution in 2008 and 2013 (HUIPS 2008 and 2013). Mothers who reside in an urban area and more-educated mothers are also more likely to use some form of childcare services compared to their respective counterparts (HUIPS 2008 and 2013).

The same surveys also provide insight into the causes of low female labor force participation in Turkey. Specifically, ever-married women who were employed at some point in the past were asked why they were not employed in the 12-month period prior to the survey in 2008 and in 2013. Having childcare responsibilities is the most commonly cited reason in both years, followed by identifying as a housewife (HUIPS 2008: 190; HUIPS 2013: 181). Until 2002, a married woman was required to have her husband's permission to be able to work outside the home. While the new civil code that came into effect in 2002 eliminated this requirement, the third-most commonly cited reason for not being employed is "not being allowed to work by spouse or family" (HUIPS 2008 and 2013). These survey results support other findings in the literature that a lack of affordable and quality childcare services, coupled with traditional gender roles in an institutional context that is built on the assumption of women's role as caregivers, remains one of the main determinants of low female labor force participation in Turkey. There is, however, considerable variation in the women's experiences by demographic characteristics. For instance, not surprisingly, the proportion of women who cite childcare responsibilities as a reason for not being employed is higher among women between the ages of 20-34 than their younger and older counterparts. Also, as expected, a larger share of women in rural areas and in low-income households cite "being a housewife" as a reason for not being employed compared to their counterparts.

Women's unpaid care responsibilities also consist of adult care, including care of the elderly. Turkey has a relatively young population with an old-age dependency ratio that is less than half of the OECD average (11 percent compared to 23.6, in 2013) (OECD 2016). Like childcare, there is defamilization of eldercare in Turkey. However, there are not enough facilities, and certainly not 
enough of them that are affordable. Specifically, public eldercare facilities require a copay that is nearly twice as much as the annual income of a minimum wage earner, and, together with private facilities (which are even less affordable) have the capacity to serve only 3.3 per 10,000 of the elderly in Turkey (Carkoglu and Kafescioglu 2014: 247). In terms of leave policy regarding care of ill or injured family members, only public employees are entitled to unpaid family medical leave of up to six months (Bak1rc1 2010). Further public provisions are provided for eldercare for low-income families. Reinforcing women's role as caretakers, in 2006, the conservative AKP government enacted a cash transfer policy conditional on taking care of a disabled or ill family member in low-income households (İlkkaracan 2013). This program, initiated with funds from the World Bank, is a perfect example of preferred policy instruments in a neoliberal economic context, which build on existing gender norms or ideologies rather than challenging them.

The gender inequitable policies governing work-life balance in Turkey and other state policies reinforce what Moghadam (1998b) has dubbed "the patriarchal gender contract," which she defines as "the implicit and often explicit agreement that men are the breadwinners and are responsible for financially maintaining wives, children, and elderly parents, and that women are wives, homemakers, mothers, and care-givers" (Moghadam 1998b). The gender gap in unpaid work is observed in all regions around the globe, but is largest in the MENA region, primarily because men there perform considerably less unpaid work, on average, than in other regions, but also because women in the MENA region perform slightly more unpaid work than their counterparts in other regions (Ferrant, Pesando, and Nowacka 2014). In Turkey, on more than one occasion President Erdogan (as prime minister, and later as president) encouraged families to have at least three children and more recently declared that "no Muslim family" should use birth control or family planning (Hurriyet Daily News 2013; BBC 2016). Yet, while the fertility rate of 2.1 in Turkey (2005/2010) exceeds that in any EU country, it remains comparable to the regional average for Latin America and the Caribbean, as well as with some other relatively low fertility Muslim-majority countries, such as Bangladesh and Iran (Eurostat 2016; UNDP 2015; World Bank, n.d.a.). 
In Turkey, the mean age at first marriage is 23.9 years for women, which is considerably lower than southern European countries and similar to eastern European countries (TSI 2016b; Eurostat 2016). The mean age at first marriage for men is 27 years. There are considerable gender differences in educational attainment. For instance, 9.2 percent of women, compared to only 1.8 percent of men are illiterate, and a larger share of men are high school graduates and college graduates compared to women (TSI 2016b). The gender gap in education is closely linked to the gender employment gap. Women with a tertiary education are more than twice as likely to participate in the labor force than women with less than an upper-secondary education (TSI 2016b). The gender disparity in labor force participation narrows with the level of education, from 29.7 percentage points between women and men with less than an upper secondary education, to 9.4 percentage points between women and men with a tertiary education. ${ }^{3}$ These statistics have led a number of scholars to argue that the key to increasing women's employment in Turkey is to improve their human capital, namely, their educational attainment and labor market experience (Başlevent and Onaran 2003; Dayığlu and Kırdar 2010). However, other scholars have emphasized the role played by other supply-side factors that point to institutional constraints (such as lack of affordable quality childcare services), as well as demand-side factors in explaining women's underrepresentation in labor markets. At the macroeconomic level, for instance, feminist economists have argued that the export-led growth strategy pursued by Turkey in the post-1980 period has not generated enough employment opportunities for women in urban labor markets, and traditional gender roles and patriarchal norms have been institutionalized as "binding constraints on women's labor supply," a phenomenon observed in other patriarchal economies in the global South (Ilkkaracan 2012: 3; Braunstein 2014).

Moreover, given the availability of cheap male labor, gender discrimination in labor markets continues (Eyüboğlu, Özar, and Tanrı̈̈ver 2000). Qualitative analyses of women's labor force participation in Turkey also find that while some less-educated women in low-income households perceive labor market engagement as a means to increased autonomy and personal fulfillment, others choose not to enter paid employment in the face of "poor working conditions offered under market liberalization" (Illkkaracan 2012: 30). These findings, also observed in other countries with similar labor market conditions for women, underline the importance of demand-side policies in

\footnotetext{
${ }^{3}$ Authors' calculations from TSI data.
} 
labor markets to increase women's labor force participation (Bahramitash and Olmsted 2014). Specifically, enforcement of antidiscrimination legislation, a labor market that generates good jobs (especially for women), and gender equitable work-family reconciliation policies are necessary to increase women's participation in the labor market in Turkey. It is within this context that we explore gender differences in time use across the life cycle.

\section{FEMINIST LITERATURE ON GENDER DISPARITIES IN TIME USE}

Gender analyses of time use across the life cycle identify the impact of different life events and roles on gender differences in time use, and comparative studies highlight the important role of the institutional context in these analyses. Among the determinants of gender differences in time use across the life course is parenthood, which tends to be associated with longer paid work hours for men, but shorter paid work hours for women (Anxo et al. 2007; Connelly and Kimmel 2010). For employed women, parenthood might also increase the total work burden, a phenomenon commonly known as "the second shift" or "double day" for women (Hochschild and Machung 1989; Schor 1991).

Evidence from several European economies and the US shows considerable gender differences in time use over the life cycle. For instance, although parenthood tends to be associated with an increase in the time men allocate to paid work and the opposite holds for women, there is considerable variation in gender disparities in time use across countries (Anxo et al. 2011; Drobnič, Blossfeld, and Rohwer 1999). For instance, using longitudinal data to explore how women's employment varies with childbirth in Germany, Sweden, and Great Britain, Gustafsson et al. (1996) find that women in Sweden are more likely to be employed after childbirth than their counterparts in Germany and Great Britain. National differences in gender disparities in time use reflect the differences in "family policy regimes," i.e., work-family reconciliation policies and the tax and benefits system (Gustafsson et al. 1996). Welfare regime - in particular, whether the state provides support to families with children and targets public sector employment-also affects whether women participate in paid work after entering parenthood. Anxo et al. (2011) explore the gender differences in time use over the life cycle in France, Italy, Sweden, and the US and find 
large gender differences in time use at each life stage in all of these countries. However, gender disparities in market and nonmarket labor are smallest in Sweden (a social democratic welfare regime, which the authors argue is more conducive to mothers' labor force participation) when compared to both Great Britain (a liberal welfare regime) and Germany (a conservativecorporatist welfare regime).

In a number of economies in the global South, time use studies and qualitative analyses have established that women's work is primarily unpaid, while men predominantly engage in paid work activities (Benería 2003; Benería, Berik, and Floro 2015). ${ }^{4}$ Women's concentration in unpaid work activities is associated with higher poverty rates for women than men, measured in terms of both income and time poverty (Antonopoulos and Hirway 2009; Bittman and Folbre 2004; Elson and Cagatay 2000; Floro 1995; K1z1lırmak and Memis 2009). The gender and macroeconomics literature has also generated evidence of the gendered outcomes of macroeconomic policies, such as in the implementation of structural adjustment programs in the global South. Fiscal austerity - in particular, cuts in publicly provided education and health services - increases women's unpaid work burden as the primary caretakers of children, the elderly, and the sick (Antonopoulos and Memis 2010; Elson 1993; Seguino 2010). In times of economic crises, women's unpaid labor acts as an invisible safety net, providing the means of survival, particularly for low-income households. For instance, women's unpaid work burden increased in Turkey during the 2007-08 recession (Kaya Bahçe and Memiş 2013). Women’s paid work burden may also increase during economic crises, as women enter the workforce to compensate for the loss of household income due to spousal job loss (Rubery 2013). For instance, the 2001 economic crisis in Turkey led to an increase in the female labor force participation rate (Kizilırmak 2008). An increased paid work burden without a compensating decline in women's unpaid work burden will increase women's total (paid and unpaid) work burden, leading to a "double shift."

Empirical examination of the gendered outcomes of macroeconomic phenomena and policies, as well as other gender disparities in time use, is now possible thanks to time use surveys, which have been conducted in some developed countries since 1960 and in most developing economies

\footnotetext{
${ }^{4}$ See Berik, Benería, and Floro (2015) for a review of these studies.
} 
since the end of the 1990s (Hirway 2009). Turkey is an exception, as the first and only nationally representative time use survey was conducted only recently, in 2006. Since then, the survey was conducted again in 2014-15. However, the 2014-15 data has not yet been released by the time of our study. Prior to the nationally representative 2006 survey, a pilot time use survey was conducted in eight provinces in $1996 .{ }^{5}$ Using data from this pilot survey, several studies have accounted for women's unpaid work. For instance, Kasnakoğlu, Dayığlu, and Erdil (1996) estimated the value of women's household production and found that it accounts for 15 percent of household income in middle-income households. In low-income households, women's contribution to household production is as high as 50 percent of the household income (Kasnakoglu and Dayioglu 2002; Kasnakoğlu, Dayığlu, and Erdil 1996). Kasnakoğlu and Dayığlu (2002) also use data from the 1996 pilot survey and, using alternative valuation methods, find that women's household production corresponds to 31-40 percent of the household income, while men's household production corresponds to 10-18 percent of the total household income. More recently, using data from the 2006 time use survey, İlkkaracan and Gündüz (2009) estimate that women contribute 79-89 percent of the total household production. Also exploring the 2006 data through a gender lens, Memiş, Ones, and Kizılırmak (2011) looked at the gender inequalities in paid and unpaid work over the life cycle and found large gender disparities in both paid and unpaid work, regardless of marital status, parenthood status, and rural/urban residence. They dubbed the persistence of the traditional gender division of labor across different demographics the "housewifization” of women in Turkey (Memiş, Öneş, and Kızılırmak 2011).

In this study, using data from the same data set, we explore the gender disparities in time use over the life course. Our study differs from Memiş, Öneş, and Kızılırmak (2011) in that we construct stylized household typologies and our analysis includes the age of household children, which, in the Turkish context of limited public provisioning of childcare services coupled with the genderasymmetric work-life reconciliation policies discussed above, is an important determinant of gender differences in paid and unpaid work time. In incorporating the age of household children in our analysis, we aim to provide a more complete picture of employment profiles and other forms of time use, which could inform social and economic policies governing work-life balance, social assistance programs, and labor market policies in Turkey. That our methodology is similar

\footnotetext{
${ }^{5}$ Ankara, Antalya, Erzurum, Eskişehir, Gaziantep, İstanbul, İzmir, and Trabzon.
} 
to Anxo et al. (2011) allows a rough comparison of our findings for Turkey to earlier findings in the literature for other countries, specifically Italy, Sweden, France, and the US.

\section{DATA AND METHODOLOGY}

The 2006 time use survey data were collected through interviews and daily time diaries. Household members provided data for a weekday and a weekend day, where they record their daily activities in ten-minute intervals for 24 hours. All members of the household kept their diary on the same day. Each day of the week is equally represented, and survey weights enable nationally representative results. Daily activities are classified according to the Eurostat (2000) activity codes. If the respondent was involved in more than one activity simultaneously, one of these activities is identified as the primary activity and the data show the time spent on this primary activity in 24 hours; the data on secondary activities are not made available by the TSI. Therefore, we examine the time spent on primary activities.

To proxy the gender division of labor among married and cohabiting women and men, we limit our sample to married and cohabiting women and men who are at least 15 years old. In our sample, there are 5,372 married and cohabiting women and men in 2,686 households. We present the labor force status of women and men in the 2006 data and in our sample in table 1 . In the survey, 23 percent of women and 69 percent of men are employed, and 1 percent of women and 5 percent of men are unemployed. ${ }^{6}$ More than half (59 percent) of the women identify as a housewife. In our sample of married and cohabiting couples, the share of women who identify as a housewife is even higher (70 percent), probably reflecting the impact of marriage on women's participation in the labor force.

\footnotetext{
${ }^{6}$ These numbers are consistent with the statistics from the household labor survey, the official source for employment indicators in Turkey (TSI 2016).
} 
Table 1. Labor Force Status by Gender (\%)

\begin{tabular}{|c|c|c|c|c|c|c|}
\hline & \multicolumn{3}{|c|}{2006 time use survey } & \multicolumn{3}{|c|}{$\begin{array}{l}\text { Married and cohabiting } \\
\text { couples }\end{array}$} \\
\hline & Men & Women & Total & Men & Women & Total \\
\hline Employed & 69 & 23 & 45 & 78 & 20 & 49 \\
\hline Unemployed & 5 & 1 & 3 & 2 & 0 & 1 \\
\hline Student & 7 & 6 & 7 & 0 & 0 & 0 \\
\hline Retired & 13 & 3 & 8 & 16 & 3 & 10 \\
\hline Elderly and disabled & 3 & 5 & 4 & 2 & 2 & 2 \\
\hline Housewives & 0 & 59 & 31 & 0 & 74 & 37 \\
\hline \multirow[t]{2}{*}{ Other } & 3 & 2 & 2 & 1 & 0 & 1 \\
\hline & 100 & 100 & 100 & 100 & 100 & 100 \\
\hline Number of observations & 5,154 & 5,739 & 10,893 & 2,686 & 2,686 & 5,372 \\
\hline
\end{tabular}

Source: Authors' calculations from the 2006 time survey data.

Table 2 presents the distribution of employed women and men across types of employment. In the survey, 62 percent of the employed women and 49 percent of the employed men are either selfemployed, daily wage workers, or unpaid family workers. In our sample of married and cohabiting couples, 62 percent of the employed women and 40 percent of men are either selfemployed, daily wage workers, or unpaid family workers. Self-employed, daily wage workers, and unpaid family workers are likely to be outside the social security system. Accordingly, while we use "paid work" and "market work" interchangeably throughout the study, market hours do not necessarily generate any income.

Table 2. Distribution of Employed Women and Men by Type of Employment (\%)

\begin{tabular}{lcccccc}
\hline & \multicolumn{3}{c}{ 2006 time use survey } & \multicolumn{3}{c}{ Married and cohabiting } \\
& \multicolumn{3}{c}{ couples } \\
\cline { 2 - 7 } & Men & Women & Total & Men & Women & Total \\
\hline Regular wage workers & 48 & 41 & 46 & 51 & 38 & 49 \\
Causal workers & 12 & 7 & 11 & 11 & 8 & 10 \\
Employer & 7 & 1 & 5 & 9 & 1 & 7 \\
Self employed & 27 & 12 & 23 & 29 & 13 & 25 \\
Unpaid family worker & 6 & 39 & 15 & 0 & 40 & 8 \\
Number of observations & 3,499 & 1,358 & 4,857 & 2,053 & 542 & 2,595 \\
\hline
\end{tabular}

Source: Authors' calculations from the 2006 time survey data. 
We define paid work as the time spent on market work and related activities, such as travel time, breaks at work, and job search activities. We cannot distinguish between paid work hours and the time spent on job searches, because the data on detailed paid work activities are not available. We define unpaid work as the sum of housework and care work. Housework includes food preparation, dishwashing, cleaning, laundry, ironing, gardening, repairing, shopping, and other activities related to home production or maintenance. Care work includes all activities related to caring for household members. We calculate it as the sum of the time spent on childcare and adult care. Personal care encompasses sleep and other personal care activities. Education is any time spent on an educational activity. Leisure includes socializing, entertainment, sports, hobbies, and games.

For the life course analysis, we use a variant of the household typologies from Anxo et al. (2011), which reflect the main transitions through the life course. In our study, these include union formation (couples of childbearing age who do not have children), different stages of parenthood, midlife "empty-nest," and retirement. Table 3 presents these typologies and the distribution of women and men across them. Our reference group in our empirical analysis is younger couples without children where the woman in the sample is younger than 46 years of age. Throughout the study, we refer to this group as "younger couples without children." Like Anxo et al. (2011), our approach is based on a cross-sectional, rather than longitudinal, time use survey. While we aim to identify patterns of gender division of paid and unpaid work over our stylized life course, we recognize the possibility that the variations across the life stages might, at least in part, reflect cohort effects.

\section{EMPLOYMENT PROFILES ACROSS THE LIFE CYCLE}

We begin with an examination of the employment profiles of married women and men across the life cycle, which are shown in figure 1. As expected, men's employment profile over the life cycle follows an inverted-U shape (i.e., men's employment rate reaches a high point when men transition into fatherhood and declines afterwards, reaching a low point during the retirement phase). Women's employment profile is quite different than men's. For women, transition into 
parenthood is associated with a considerably (10 percentage point) lower employment rate. As household children grow up, the employment rate for mothers increases until they transition into the empty-nest stage. In Turkey, the official age to be eligible for a pension is 58 for women and 60 for men, and until 2010, an individual could retire as early as 45 due to an alternative eligibility condition of having worked for 25 years. Low employment rates for both women and men during the empty-nest stage may reflect the ability to retire at a relatively young age due to this alternative eligibility condition.

\begin{tabular}{lc} 
Table 3. Sample by Household Types (\%) & \\
\hline In sample & 1 \\
\hline 1: Younger couples (woman under age 46) without children & 13 \\
2: Couple with youngest children (mean age of children: under 6 years) & 25 \\
3: Couple with young children (mean age of children: 6-15 years) & 15 \\
4: Couple with teenage children (mean age of children: 16-25 years) & 3 \\
5: Midlife "empty-nest" couples without resident children, (woman & \\
age 45-59) & 2 \\
6: Older retired couples without resident children (both spouses age & 10 \\
60 years or older) & 18 \\
\hline Not in sample & 10 \\
\hline Couple households not covered in above couple groups & 2 \\
Extended family households & 100 \\
Extended other family households & \\
Other (single or people living together no relation) & \\
Total &
\end{tabular}

Note: Weighted shares in sample using survey weights.

Source: Authors' calculations from the 2006 time survey data.

That the male breadwinner model predominates in Turkey is reflected in the large gender employment gap at each life stage. The gap is largest at 78 percentage points among parents of younger children, which is not surprising given the gender-asymmetric parental leave policy in Turkey, combined with very limited affordable and quality childcare services and even more limited public provisioning of childcare for preschool age children. As household children grow up, the gender employment gap narrows. However, even among couples without children, there is a substantial (55 percentage point) employment gap, reflecting the traditional gender division of labor, even in the absence of children. The empty-nest stage is associated with a narrower gender 
gap in employment, primarily due to a lower employment rate for men at this stage. The gender gap in employment is even narrower during the retirement phase, but is still 19 percentage points, possibly because women become eligible for a pension at a younger age than men.

\section{Figure 1. Profile of Employment Rates over the Life Course by Gender}

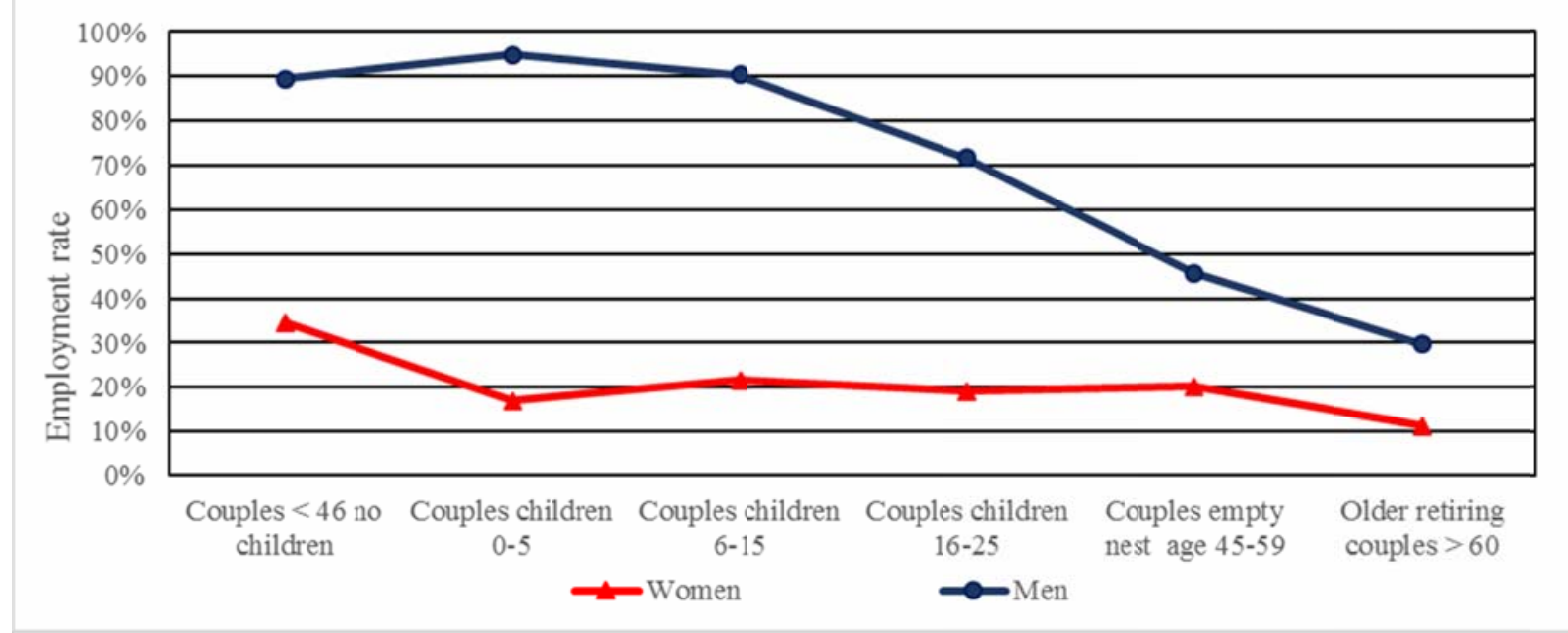

Source: Authors' calculations from the 2006 time use survey.

The observed gendered employment profiles across our stylized life course might, in part, reflect differences in individual and household characteristics. Controlling for these differences, we estimate the employment rates of women and men using a probit model. Specifically, we include control variables for educational attainment, household income, the number of rooms in the house, rural/urban residence, and day of the week to which the time diary refers. Education is a strong determinant of labor force participation, especially for women in Turkey. The number of rooms in the house is a determinant of the time spent on housework. Higher household income allows for purchases of market substitutes for home-produced goods and services, including childcare services. Rural/urban residence captures the rural/urban differences in women's labor force participation and employment opportunities. We also control for the day of week, which is expected to be a determinant of time use. The results of our estimation are presented in table 4 . $^{7}$ We calculate the predicted employment rates for women and men at each life stage with these controls and present them in table 5. In both tables, the control group is couples without children. Our estimations confirm that a woman's transition into parenthood is associated with an

\footnotetext{
${ }^{7}$ For brevity, we present the results only for our stylized household typologies for this and other estimations throughout the paper. Full regression results are available from the authors upon request.
} 
employment rate that is 16 percentage points lower compared to women without children.

The presence of school-age children has less of a negative impact on women's employment rate (10 percentage points) compared to the presence of preschool-age children. Women's employment rate is increasingly lower at later stages across our stylized life course, reaching a low point of 10 percent during the retirement phase. Men's employment rate increases by 5 percentage points with transition into parenthood. The employment rate of fathers of school-age children is not statistically significantly different than that of their younger counterparts without children. Men's employment rate declines significantly at each stage after that, reaching a low point of 35 percent during the retirement phase.

Paid work hours of employed women and men on an average day exhibit similar patterns to women's and men's employment rates across the life cycle (figure 2). However, employed men work the longest hours when they do not have children, and their paid work hours are increasingly lower at each stage after that, reaching a low point during the retirement phase.

Employed women engage in market work the longest number of hours before they have children, and the transition to motherhood is associated with approximately two fewer hours of paid work for women. Compared to mothers of preschool-age children, as well as mothers without coresident children during the empty-nest phase, employed mothers of older children have longer paid work hours. Like their male counterparts, employed women's paid work hours are shortest during the retirement phase, as expected. Employed men work longer hours than employed women at each life stage, but the difference is largest ( 3 hours) among parents of preschool-age children. The gap is narrower among parents of older children and also during the empty-nest stage. During the retirement stage, the gender difference in paid work hours is larger compared to the empty-nest stage, possibly reflecting the gender difference in the retirement age in Turkey. 
Table 4. Impact of Changes in Household Typologies on Employment Rate (Selection Effect) (Probit Estimates) by Gender

Household life course typologies Women Men

Reference: couple<46 no children

Couple with children ages $0-5$

$-0.551 * * *$

$0.412 * *$

Couple with children ages 6-15

(0.166)

$-0.301 * *$

0.0402

(0.132)

$(0.154)$

Couple with children ages 16-25

$-0.416^{* * *}$

$-0.762 * * *$

(0.143)

(0.155)

Couple, empty-nest age 45-59

$-0.489 * * *$

$-1.474 * * *$

(0.157)

Older retiring couples $>60$

$-0.729 * * *$

(0.165)

(0.178)

$-1.735^{* * *}$

2,686

(0.173)

Number of observations

0.1266

2,686

Pseudo R2

Notes: Standard errors in parentheses. $* * * \mathrm{p}<0.01, * * \mathrm{p}<0.05, * \mathrm{p}<0.1$

Table 5. Predicted Values of Employment Rate by Gender and Household Typologies (\%)

\begin{tabular}{lcc}
\hline & Women & Men \\
\hline Couple $<46$ no children & 30 & 91 \\
Couple with children ages 0-5 & 14 & 96 \\
Couple with children ages 6-15 & 20 & 92 \\
Couple with children ages 16-25 & 17 & 72 \\
Couple, empty-nest age 45-59 & 16 & 45 \\
Older retiring couples $>60$ & 10 & 35 \\
\hline
\end{tabular}

Source: Authors' calculations.

Note: We predict the employment rates for women and men at each life stage by setting each control variable equal to their mean values. 
Figure 2. Daily Paid Work Hours of Employed Women and Men (Hours and Minutes/Day)

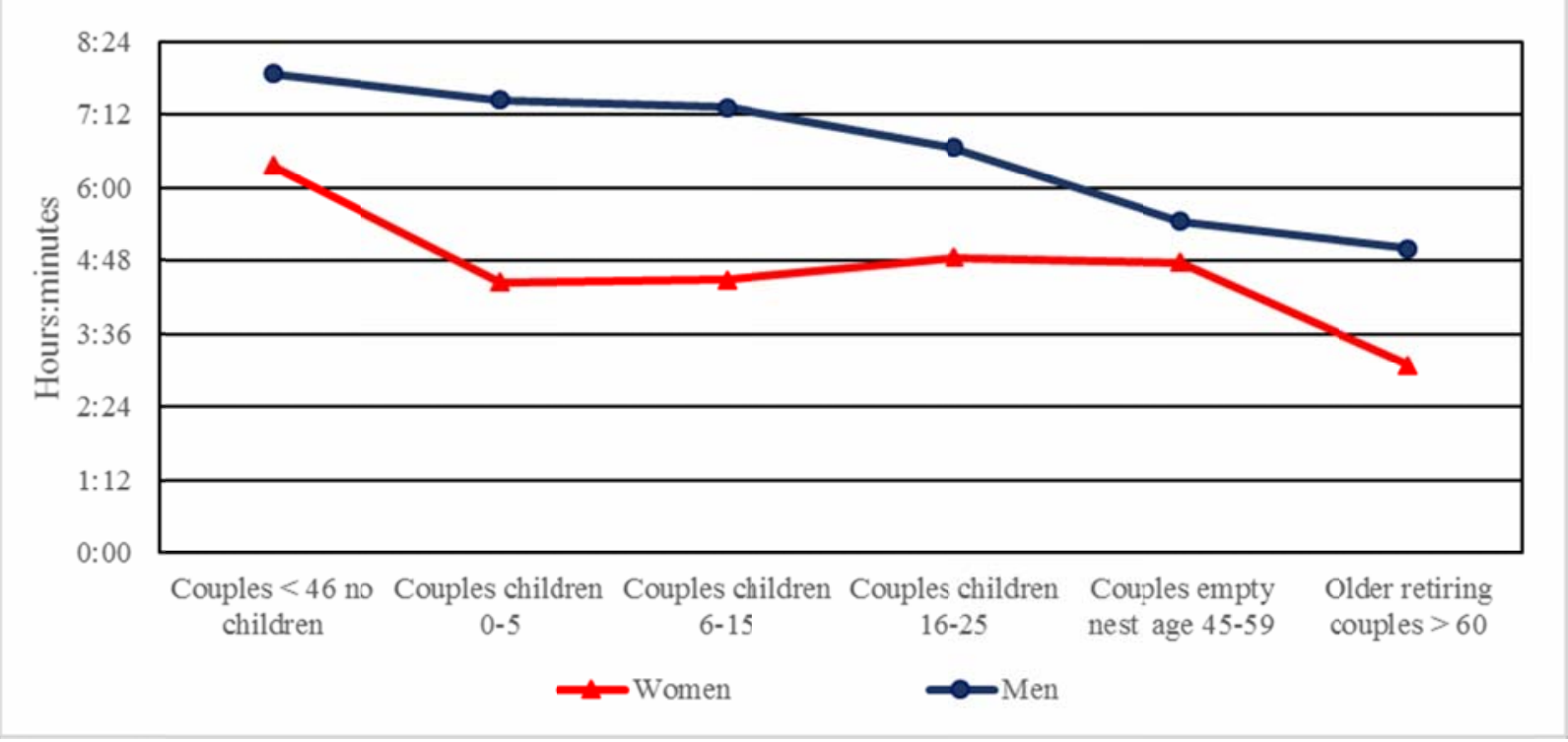

Source: Authors' calculations from the 2006 time use survey.

To control for the effects of individual and household characteristics, we estimate hours of paid work equations for employed women and men using a generalized Tobit model, with the same control variables discussed above. The results of our estimation are presented in table 6 . The control group is couples without children. Compared to employed women without children, mothers of preschool-age children have significantly shorter paid work hours, possibly due to the effect of maternity leave and the transition into part-time work. The coefficients are negative but insignificant in all other stylized life stages (i.e., for employed mothers, the negative effect of children on paid work hours disappears as children grow up). Like their female counterparts, compared to men without children, fathers of preschool-age children have fewer paid work hours; however, employed men's paid work time continues to become shorter as they progress through the stages of our stylized life course, unlike employed women. 


\begin{tabular}{|c|c|c|}
\hline $\begin{array}{l}\text { Household life course typologies } \\
\text { Reference: couple }<46 \text { no children }\end{array}$ & Women & Men \\
\hline Couple with children ages $0-5$ & $\begin{array}{c}-123.2 * * \\
(52.78)\end{array}$ & $\begin{array}{c}-34.27^{*} \\
(20.63)\end{array}$ \\
\hline Couple with children ages $6-15$ & $\begin{array}{l}-61.17 \\
(49.04)\end{array}$ & $\begin{array}{c}-37.78^{*} \\
(19.82)\end{array}$ \\
\hline Couple with children ages $16-25$ & $\begin{array}{c}-65.29 \\
(50.23)\end{array}$ & $\begin{array}{c}-81.48 * * * \\
(22.29)\end{array}$ \\
\hline Couple, empty-nest age $45-59$ & $\begin{array}{l}-18.66 \\
(53.96)\end{array}$ & $\begin{array}{c}-118.4 * * * \\
(28.34)\end{array}$ \\
\hline Older retiring couples $>60$ & $\begin{array}{l}-74.05 \\
(64.25)\end{array}$ & $\begin{array}{c}-135.2 * * * \\
(35.14)\end{array}$ \\
\hline Number of observations & 542 & 2,053 \\
\hline LR & 61.23 & 194.32 \\
\hline Pseudo-R2 & 0.0098 & 0.0075 \\
\hline Censored observations & 116 & 212 \\
\hline
\end{tabular}

Notes: Standard errors in parentheses. ${ }^{* * *} \mathrm{p}<0.01,{ }^{* *} \mathrm{p}<0.05,{ }^{*} \mathrm{p}<0.1$

\section{GENDER AND UNPAID WORK OVER THE LIFE CYCLE}

To examine gender differences in the unpaid work burden, in figure 3 we present the time married and cohabiting women and men spend on unpaid work across the life cycle. Young mothers of preschool-age children spend 2 hours and 45 minutes more in unpaid work activities than young women without children. Women's unpaid work burden declines as children age: mothers of younger children spend 1 hour and 22 minutes less than mothers of preschool-age children in unpaid work activities, and mothers of teenagers spend about an hour less than mothers of younger children in unpaid work activities as their childcare time declines. In fact, mothers of teenage children spend about as much time as their childless counterparts in unpaid work activities. Women's unpaid work time remains relatively unchanged in later stages in life, specifically during the empty-nest phase and when they transition into retirement. Compared to women, men's unpaid work burden over the life course is relatively flat (i.e., men's unpaid work time varies by at most a half hour across different life stages). Nevertheless, fatherhood is associated with a slightly higher unpaid work burden compared to men without children. Like women, men's unpaid work gradually declines as children age. However, during the midlife 
empty-nest stage, men spend more time in unpaid work activities compared to fathers of teenage children, and men's unpaid work time reaches a high point during the retirement phase. The gender disparity in unpaid work and the gender gap in paid work mirror each other: women spend about four hours more in unpaid work activities than men at each life stage. The gender difference in unpaid work is largest among parents of younger children, at nearly seven hours (6 hours and 49 minutes). However, even women without children spend four-and-a-half hours more in unpaid work activities than their male counterparts. The gender gap in unpaid work time narrows slightly as children grow up, mainly because the time women spend on childcare activities declines at these later stages (table 7).

Table 7 shows the daily time women and men spend on housework, childcare, and other activities. ${ }^{8}$ We see that the transition into parenthood intensifies the gendered patterns of time use, primarily because women spend considerably more time than men in childcare activities. However, women also increase their housework time more than men when they transition into parenthood. After this initial increase, the time women spend on housework remains relatively unchanged in the later stages of our stylized life cycle. Compared to mothers, fathers spend considerably less time on housework activities across the life course, only increasing their housework time during the midlife empty-nest stage when men are less likely to be in the labor force compared to the fathers of teenage children, possibly reflecting eligibility for pension at a relatively young age. ${ }^{9}$

\footnotetext{
${ }^{8}$ Mean duration of each activity reflects the sample mean for all respondents, including those who have not engaged in that activity. Accordingly, the relatively lower time women spend on paid work activities in part reflects their relatively lower employment rate.

${ }^{9}$ These results are available from the authors upon request.
} 
Figure 3. Daily Unpaid Work Hours by Gender (Hours and Minutes/Day)

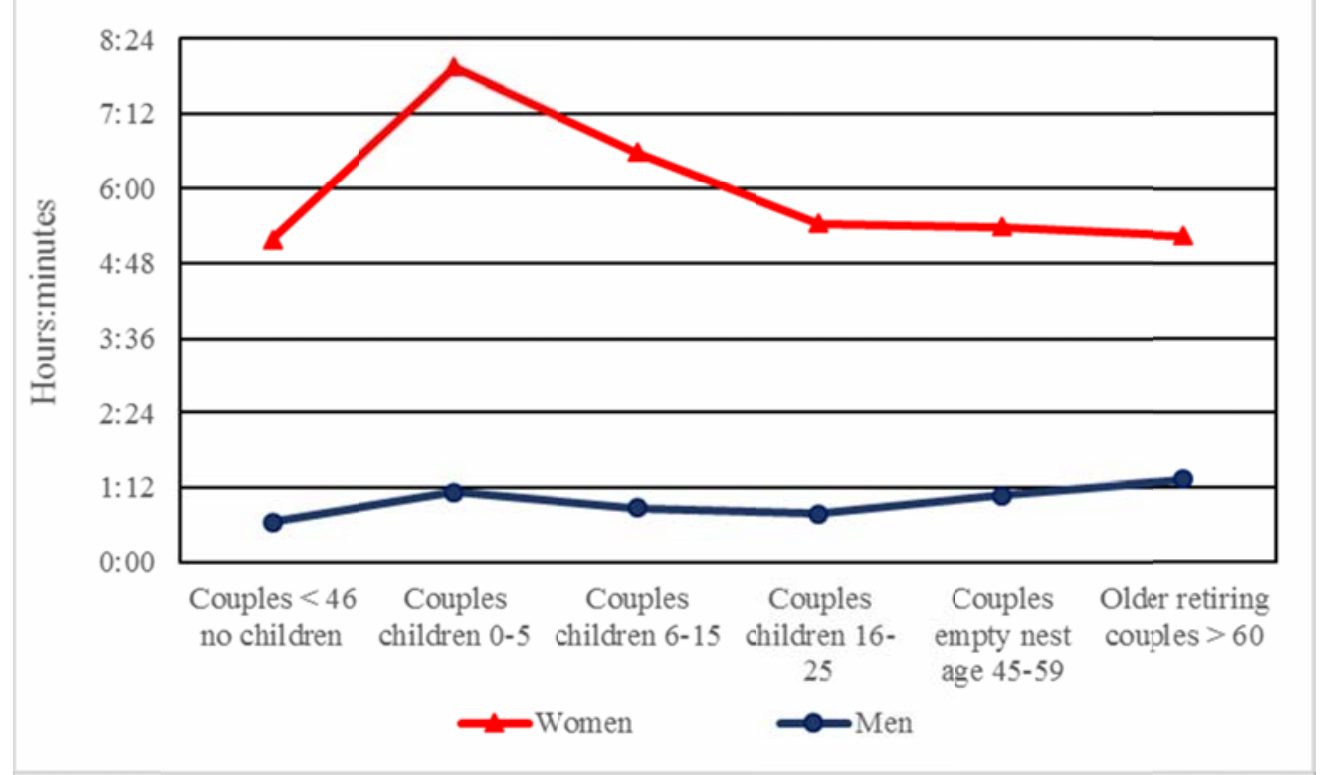

Source: Authors' calculations from the 2006 time use survey.

We estimate the unpaid work hours of women and men, controlling for the individual and household characteristics discussed earlier in the study. ${ }^{10}$ Our estimations, presented in table 8 , confirm that parents of the youngest children spend significantly more time on unpaid work compared to their counterparts without children. Using some elementary calculations, we convert the estimated coefficient into hours and find that, compared to women without children, mothers of preschool-age children spend about two-and-a-half hours more per day on unpaid work activities. ${ }^{11}$ Fathers of preschool-age children spend a half hour more on unpaid work activities than men without children. Women with young children (between the ages of 6-15) spend an hour more on unpaid work activities than women without children. Confirming our findings above, in later stages of our stylized life course, the time women spend on unpaid work is not

\footnotetext{
${ }^{10} \mathrm{We}$ control for educational attainment, household income, number of rooms in the house, rural/urban residence, and day of the week.

${ }^{11}$ We calculate the two-and-a-half-hour difference in the unpaid work time of mothers of youngest children as follows: We first calculate the scale factor as the ratio of the number of uncensored observations to the total number of observations for the women in the sample (i.e., of the 2,686 women in the sample, only eight do not perform any unpaid work on an average day). The scale factor is the proportion of non-zero respondents in the sample. Accordingly, the scale factor for women can be calculated as the ratio of women who have spent some time in unpaid work activities to the total number of women in the sample, which is equal to 0.997 . We multiply this scale factor with the coefficient presented in table 7 for women with the youngest children and find that they spend 2 hours and 37 minutes more than women without children. The scale factor is equal to 0.56 for the men in the sample. Through the calculations above, we find that fathers of the youngest children spend a half hour more in unpaid work activities than men without children.
} 
statistically significantly different compared to younger women without children. In other words, after children grow up to be teenagers, women's unpaid work burden seems to go back to its preparenthood level. Our findings for fathers are also confirmed. Fathers of older children spend less time in unpaid work compared to fathers of preschool-age children. Compared to men without children, during the empty-nest and retirement stages, men spend more time in unpaid work activities. A closer look at the types of housework men do during these later stages in life shows that men increase the time they spend on yardwork, shopping, and house maintenance. ${ }^{12}$

\footnotetext{
${ }^{12}$ These results are available from the authors upon request.
} 
Table 7. Daily Hours of Time Use by Gender and Household Typology (Hours and Minutes/Day)

\begin{tabular}{|l|c|c|c|c|c|c|c|c|c|c|c|c|}
\hline & \multicolumn{10}{|c|}{ Women } & \multicolumn{1}{|c|}{ Men } \\
\cline { 2 - 10 } Household Typology & 1 & 2 & 3 & 4 & 5 & 6 & 1 & 2 & 3 & 4 & 5 & 6 \\
\hline Time use category & \multicolumn{10}{|c|}{ | } \\
\hline Personal care & $11: 28$ & $10: 36$ & $10: 52$ & $11: 14$ & $11: 09$ & $11: 12$ & $11: 13$ & $10: 48$ & $10: 59$ & $11: 19$ & $11: 21$ & $11: 20$ \\
Paid work & $1: 46$ & $0: 30$ & $0: 56$ & $0: 49$ & $1: 00$ & $0: 33$ & $5: 46$ & $5: 51$ & $5: 32$ & $4: 04$ & $2: 34$ & $1: 14$ \\
Education & $0: 02$ & $0: 00$ & $0: 01$ & $0: 02$ & $0: 00$ & $0: 00$ & $0: 03$ & $0: 01$ & $0: 00$ & $0: 01$ & $0: 00$ & $0: 00$ \\
Unpaid work & $5: 11$ & $7: 57$ & $6: 35$ & $5: 26$ & $5: 23$ & $5: 15$ & $0: 39$ & $1: 08$ & $0: 53$ & $0: 47$ & $1: 05$ & $1: 20$ \\
Housework & $4: 43$ & $5: 23$ & $5: 31$ & $5: 10$ & $5: 09$ & $5: 02$ & $0: 32$ & $0: 36$ & $0: 37$ & $0: 39$ & $0: 57$ & $1: 18$ \\
Care work & $0: 28$ & $2: 34$ & $1: 03$ & $0: 16$ & $0: 13$ & $0: 13$ & $0: 06$ & $0: 32$ & $0: 16$ & $0: 08$ & $0: 08$ & $0: 02$ \\
Total work & $6: 57$ & $8: 27$ & $7: 31$ & $6: 15$ & $6: 23$ & $5: 48$ & $6: 25$ & $6: 59$ & $6: 25$ & $4: 51$ & $3: 39$ & $2: 34$ \\
Volunteer activities & $0: 28$ & $0: 29$ & $0: 44$ & $0: 56$ & $1: 23$ & $1: 47$ & $0: 24$ & $0: 26$ & $0: 33$ & $0: 42$ & $1: 15$ & $1: 11$ \\
Leisure Socializing \& & $4: 04$ & $3: 31$ & $3: 51$ & $4: 28$ & $4: 08$ & $4: 27$ & $4: 07$ & $3: 51$ & $4: 13$ & $5: 21$ & $5: 52$ & $7: 15$ \\
entertainment & $1: 39$ & $1: 43$ & $1: 53$ & $2: 04$ & $2: 04$ & $2: 23$ & $1: 21$ & $1: 30$ & $1: 38$ & $1: 55$ & $2: 29$ & $3: 04$ \\
Sports & $0: 07$ & $0: 02$ & $0: 02$ & $0: 03$ & $0: 04$ & $0: 03$ & $0: 11$ & $0: 05$ & $0: 06$ & $0: 09$ & $0: 05$ & $0: 22$ \\
Cobbies \& games & $0: 05$ & $0: 02$ & $0: 01$ & $0: 02$ & $0: 01$ & $0: 02$ & $0: 20$ & $0: 15$ & $0: 16$ & $0: 26$ & $0: 18$ & $0: 19$ \\
Travel \& other & $0: 13$ & $1: 44$ & $1: 55$ & $2: 19$ & $1: 59$ & $1: 59$ & $2: 15$ & $2: 01$ & $2: 13$ & $2: 51$ & $3: 00$ & $3: 30$ \\
Free time & $4: 35$ & $0: 51$ & $0: 54$ & $1: 00$ & $0: 52$ & $0: 42$ & $1: 44$ & $1: 48$ & $1: 44$ & $1: 42$ & $1: 47$ & $1: 36$ \\
\hline
\end{tabular}

Source: Authors' calculations from the 2006 time use survey. 


\section{TOTAL WORK AND LEISURE OVER THE LIFE CYCLE}

To assess the total work burden of women and men and the time they spend on leisure activities, we present the time spent on these two aggregate time use categories in table 5. The time women and men spent engaged in leisure activities across the life cycle is also shown in figure 4.

Table 8. Multivariate Tobit Regression on Daily Minutes of Unpaid Work (Marginal
Effects Evaluated at Sample Mean) by Gender
\begin{tabular}{lcc} 
Household life course typologies & Women & Men \\
Reference: couple $<46$ no children & & $53.69^{* * *}$ \\
\hline Couple with children ages 0-5 & $155.7^{* * *}$ & $(13.16)$ \\
& $(15.67)$ & $34.25^{* * *}$ \\
Couple with children ages 6-15 & $64.97 * * *$ & $(12.97)$ \\
& $(15.32)$ & $27.42^{* *}$ \\
Couple with children ages 16-25 & 14.85 & $(13.77)$ \\
& $(16.24)$ & $60.80^{* * *}$ \\
Couple, empty-nest age 45-59 & 4.778 & $(14.92)$ \\
& $(17.22)$ & $75.19 * * *$ \\
Older retiring couples $>60$ & -23.45 & $(16.61)$ \\
& $(17.45)$ & 2,686 \\
Number of observations & 2,686 & 98.98 \\
LR & 419.52 & 0.0048 \\
Pseudo-R2 & 0.0119 & 1,176 \\
Censored observations & 14 & \\
\hline
\end{tabular}

Notes: Standard errors in parentheses. ${ }^{* * *} \mathrm{p}<0.01,{ }^{* *} \mathrm{p}<0.05,{ }^{*} \mathrm{p}<0.1$

Transition into parenthood is associated with a heavier total work burden for both women and men compared to their counterparts without children. Women's and men's total work burden is increasingly lower in the later stages of our stylized life course. However, the variations in the total work burden across the life course are more pronounced for women compared to men, including the effect of parenthood. Women have a heavier total work burden than men at each life stage. Controlling for individual and household characteristics, we use a Tobit model to estimate the total work burden of women and men. Our findings reported in table 9 show that the mothers of preschool-age children work one-and-a-half hours more and mothers of younger children work approximately a half hour more compared to women without children. Women who are in the later stages of life have a relatively lower work burden compared to their younger counterparts without children, and women's total work burden reaches a low point during the retirement phase. The presence of preschool-age children in the household is associated with a 40-minute longer 
total work time for fathers relative to younger men without children. The presence of teenage children in the household is associated with fewer work hours for both mothers and fathers, possibly in part because teenage children require less primary caregiving and may even share the unpaid work burden within the household. Compared to their younger counterparts without children, men in the later stages of the life course work considerably shorter hours. During the retirement phase, the difference is slightly more than three-and-a-half hours.

Using Bianchi and Wight's (2010) definition, we calculate the "free time" available to women and men as the residual time after deducting the time spent on paid work, unpaid work, and personal care. Women's and men's free time follow a similar pattern to their leisure time. The time women and men spend on personal care (mainly sleep) over the life course varies less than their leisure time. Young parents, however, spend less time in personal care activities than their childless counterparts. Both women and men slightly increase their personal care time as children grow up. Compared to childless couples, mothers of preschool-age children spend about 50 minutes less on personal care activities, while fathers of young children spend about 25 minutes less. Women's heavier total work burden is reflected in the gender disparity in leisure time rather than in personal care time, where the gender difference is small (table 7 and figure 4). Women and men spend relatively equal time in leisure activities when they do not have children. The difference becomes visible when they become parents, reflecting a larger increase in women's total work burden.

Figure 4. Time Spent on Leisure Activities per Day, by Gender (Hours and Minutes/Day)

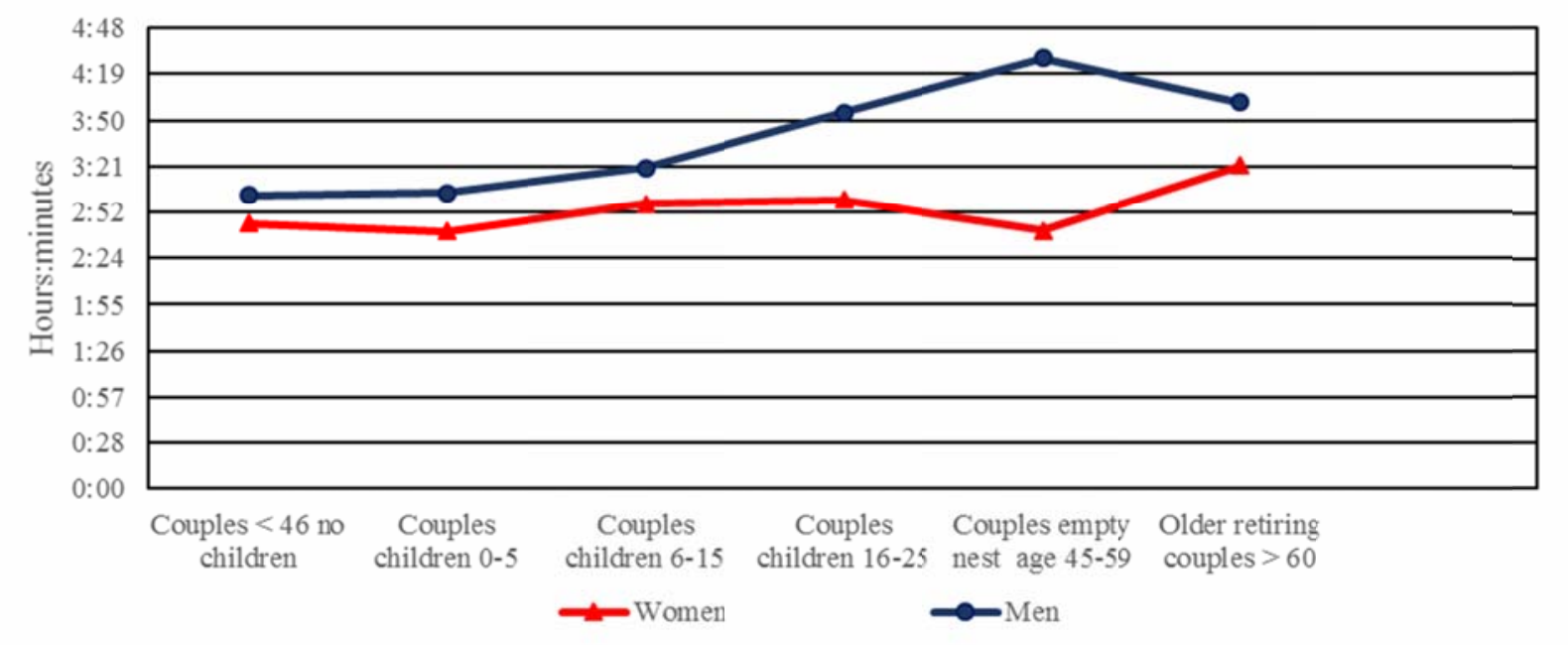

Source: Authors' calculations from the 2006 time use survey. 
Table 9. Multivariate Tobit Regression on Daily Minutes of Total (Paid and Unpaid) Work (Marginal Effects Evaluated at Sample Mean) by Gender

\begin{tabular}{lcc}
\hline $\begin{array}{l}\text { Household life course typologies } \\
\text { Reference: couple }<46 \text { no children }\end{array}$ & Women & Men \\
\cline { 1 - 1 } & & \\
Couple with children ages 0-5 & $86.96^{* * *}$ & $44.86^{* *}$ \\
& $(14.72)$ & $(18.30)$ \\
Couple with children ages 6-15 & $28.76^{* *}$ & -5.869 \\
& $(14.48)$ & $(18.01)$ \\
Couple with children ages 16-25 & $-42.70^{* * *}$ & $-107.2^{* * *}$ \\
& $(15.28)$ & $(19.63)$ \\
Couple, empty-nest age 45-59 & $-37.03 * *$ & $-198.4^{* * *}$ \\
& $(16.26)$ & $(21.73)$ \\
Older retiring couples $>60$ & $-93.32^{* * *}$ & $-245.5^{* * *}$ \\
& $(16.92)$ & $(24.77)$ \\
Number of observations & 2,686 & 2,686 \\
LR & 738.87 & 1145.78 \\
Pseudo-R2 & 0.0104 & 0.0166 \\
Censored observations & 14 & 297 \\
\hline
\end{tabular}

Notes: Standard errors in parentheses. ${ }^{* * *} \mathrm{p}<0.01, * * \mathrm{p}<0.05, * \mathrm{p}<0.1$

At later stages in life, the leisure gap widens, reflecting the combination of a decline in men's paid work hours and a relatively unchanged housework burden for women. We estimate the time women and men spend on leisure activities using an ordinary least squares model since we expect all women and men to have spent some time on leisure activities. Our estimates show that compared to younger women without children, mothers of preschool-age children spend less time on leisure activities (table 10). The negative impact children have on leisure time disappears when children reach school age, and the effect of children becomes positive as they become teenagers, possibly as childcare during this stage takes the form of secondary childcare during leisure activities, and also as teenagers shoulder some of the unpaid work burden. 
Table 10. Multivariate OLS Estimates of Leisure Time by Gender

\begin{tabular}{lcc}
\hline & $(1)$ & $(2)$ \\
Household life course typologies & Women & Men \\
Reference: couple $<46$ no children & & -3.385 \\
\hline Couple with children ages $0-5$ & $-21.39 *$ & $(12.75)$ \\
& $(12.10)$ & 20.15 \\
Couple with children ages 6-15 & 14.25 & $(12.45)$ \\
& $(12.12)$ & $102.1 * * *$ \\
Couple with children ages $16-25$ & $36.67 * * *$ & $(14.24)$ \\
& $(12.89)$ & $142.7^{* * *}$ \\
Couple, empty-nest age 45-59 & 20.18 & $(15.93)$ \\
& $(13.94)$ & $153.9 * * *$ \\
Older retiring couples $>60$ & $38.93 * * *$ & $(16.92)$ \\
& $(14.86)$ & 2,686 \\
Number of observations & 2,686 & 0.137 \\
R2 & 0.040 &
\end{tabular}

Notes: Standard errors in parentheses. ${ }^{* * *} \mathrm{p}<0.01,{ }^{* *} \mathrm{p}<0.05,{ }^{*} \mathrm{p}<0.1$

\section{DISCUSSION AND CONCLUDING REMARKS}

In this study, we constructed stylized household typologies across the life cycle to examine how different roles and events affect gendered patterns of time use among married and cohabiting couples in Turkey. Our results show that the male breadwinner norm predominates among married and cohabiting couples. Transition into parenthood is associated with even more specialization between married and cohabiting women and men: among parents of preschool-age children, the gender employment gap is as high as 78 percentage points. Compared to previous findings in the literature for Italy, France, the US, and Sweden, the effect of parenthood on the gender employment gap is considerably larger in Turkey, although the negative impact on the gender employment gap of transition into parenthood is observed in all of these countries (Anxo et al. 2011). The smallest effect is in Sweden and France, and the largest effects are observed in Italy and the US, where the gender employment gap widens to around 40 percentage points (Anxo et al. 2011: 172).

While direct comparisons are not possible due to differences in the time periods studied as well as the samples, at least in terms of the larger impact of parenthood on the gender employment gap, Turkey is more similar to Italy and the US, rather than Sweden or France. Work-life reconciliation 
policies possibly explain these similarities. For instance, like Turkey, public spending on childcare in the US is one of the lowest among OECD countries and there are limited affordable market substitutes of quality. While very different, the absence of paid parental leave (unless provided by the employer) in the US and the gender-asymmetric paid maternity leave policy in Turkey are likely to have similar outcomes in terms of specialization among married parents. In the case of Turkey, expanding the length of the recently available paid parental leave would at least potentially increase labor force participation for mothers. Public provisioning of affordable quality childcare services for children younger than six is also likely to increase women's labor force participation. On the demand side of labor markets, the current gender-asymmetric parental leave policy creates a clear disincentive to hire female employees. While gender disparities in education also contribute to gender disparities in labor market outcomes, we find a significant negative effect of parenthood on women's employment rate after controlling for education, while the opposite holds for men. Revisions to the labor law that came into effect in 2016 make provisions for working mothers with young children to work part-time as contract workers and remain in part-time employment until the child reaches school age (Turkish Labor Law 2016). While any parent, regardless of gender, is eligible for part-time work, in practice, without a challenge to existing gender norms, this policy is unlikely to have a significant impact on the traditional gender division of labor in Turkey.

Our findings show that a relatively equal work burden in the early stages of a couple's life becomes less equal in later stages, primarily due to a combination of a larger decline in men's paid work hours and a relative increase in women's housework burden in the later stages of our stylized life course.

Given that the 2006 time use data are collected for all household members, future research that examines the within-household division of paid and unpaid labor would further contribute to our understanding of the gendered patterns of time use in Turkey. When the 2014 data become available, it will be possible to examine the changes in the gendered patterns of time use between 2006 and 2014. With attention to the policy context, this comparison would contribute to our understanding of the gendered outcomes for time use of a decade of conservative policies of the AKP government. 


\section{REFERENCES}

Aguiar, Mark, and Erik Hurst. 2006. "Measuring Trends in Leisure: The Allocation of Time Over Five Decades.” Working Paper No. 12082. Cambridge, MA: National Bureau of Economic Research. Retrieved from http://www.nber.org/papers/w12082.

Altan-Olcay, Özlem. 2014. "Entrepreneurial Subjectivities and Gendered Complexities: Neoliberal Citizenship in Turkey." Feminist Economics 20(4): 445-69.

Antonopoulos, Rania, and Indira Hirway. 2009. "Unpaid Work and the Economy." In R. Antonopoulos and I. Hirway (eds.), Unpaid Work and the Economy: Gender, Time-Use and Poverty in Developing Countries. Basingstoke, UK: Palgrave Macmillan.

Antonopoulos, Rania, and Emel Memis. 2010. "Time and Poverty from a Developing Country Perspective.” Levy Institute Working Paper No. 600. Annandale-on-Hudson, NY: Levy Economics Institute of Bard College.

Anxo, Dominique, Lennart Flood, Letizia Mencarini, Ariane Pailhé, Anne Solaz, and Maria Letizia Tanturri. 2007. "Time allocation between work and family over the life-cycle: A comparative gender analysis of Italy, France, Sweden and the United States." IZA Discussion Paper No. 3193. Bonn: Institute for the Study of Labor (IZA).

Anxo, Dominique, Letizia Mencarini, Arieane Pailhé, Anne Solaz, Maria Letizia Tanturri, and Lennart Flood. 2011. "Gender differences in time use over the life course in France, Italy, Sweden, and the US." Feminist Economics 17(3): 159-95.

Bahramitash, Roksana, and Jennifer C. Olmsted. 2014. "Choice and Constraint in Paid Work: Women from Low-Income Households in Tehran.” Feminist Economics 20(4): 260-80.

Bakirci, Kadriye. 2010. "Gender Equality in Employment in Turkish Legislation with Comparisons to EU and International Law.” Journal of Workplace Rights 15(1): 3-25.

Başlevent, Cem, and Özlem Onaran. 2003. “Are Married Women in Turkey More Likely to Become Added or Discouraged Workers?" Labour 17(3): 439-58.

BBC. 2016. “Turkey’s Erdogan Warns Muslims against Birth Control.” May 30.

Retrieved from http://www.bbc.com/news/world-europe-36413097

Beneria, Lourdes. 1999. "Globalization, Gender and the Davos Man.” Feminist Economics 5(3): 61-83.

- 2003. "Economic rationality and globalization: A feminist perspective." In Marianne A. Ferber and Julie A. Nelson (eds.), Feminist Economics Today: Beyond Economic Man. Chicago: The University of Chicago Press. 
Benería, Lourdes, Günseli Berik, and Maria Floro. 2015. Gender, Development and Globalization: Economics as if all People Mattered. London and New York: Routledge.

Berik, Günseli, and Nilüfer Çağatay. 1990. "Transition to Export-Led Growth in Turkey: Is There a Feminization of Employment?" Review of Radical Political Economics 22(1): 115-34.

Bianchi, Suzanne. M. 2011. "Family Change and Time Allocation in American Families." The Annals of the American Academy of Political and Social Science 638: 21-44.

Bianchi, Suzanne M., and V. Wight. 2010. "The Long Reach of the Job: Employment and Time for Family Life.” In K. Christensen and B. Schneider (eds.), Workplace flexibility: realigning 20th-century jobs for a 21st-century workforce workers. Ithaca, NY: Cornell University Press.

Bittman, Michael, and Nancy Folbre. 2004. Family Time: The Social Organization of Care. New York: Routledge.

Braunstein, Elissa. 2014. "Patriarchy versus Islam: Gender and Religion in Economic Growth." Feminist Economics 20(4): 58-86.

Buğra, Ayşe, and Çağlar Keyder. 2006. "The Turkish Welfare Regime in Transformation." Journal of European Social Policy 16(3): 211-28.

Buğra, Ayşe, and Burcu Yakut-Cakar. 2010. "Structural Change, the Social Policy Environment and Female Employment in Turkey." Development and Change 41(3): 517-38.

Çarkoğlu, Asl1, and Nilüfer Kafescioğlu. 2014. "For Whose Sake Is It Anyway? Evaluation of Explicit Family Policies in Turkey." In Mihaela Robila (ed.), Handbook of Family Policies across the Globe. New York: Springer.

Connelly, Rachel, and Jean Kimmel. 2010. The Time Use of Mothers in the United States at the Beginning of the 21st Century. Kalamazoo, MI: W.E. Upjohn Institute.

Dayığlu, Meltem, and Murat Kurdar. 2010. “Determinants of Women's Labor Force Participation in Turkey [Türkiye'de Kadınların Işgücüne Katılımında Belirleyici Etkenler ve Eğilimler].” DPT ve Dünya Bankası Refah ve Sosyal Politika Analitik Çalışma Programı, Çalışma Raporu, no. 5: 1-82.

Drobnič, Sonja, Hans-Peter Blossfeld, and Götz Rohwer. 1999. "Dynamics of Women’s Employment Patterns over the Family Life Course: A Comparison of the United States and Germany." Journal of Marriage and the Family 61(1): 133-46.

Elson, Diane. 1993. "Gender-Aware Analysis and Development Economics." Journal of International Development 5 (2): 237-47. 
Elson, Diane, and Nilufer Cagatay. 2000. "The Social Content of Macroeconomic Policies." World Development 28(7): 1347-64.

Esping-Andersen, G. 1990. The three worlds of welfare state. New York: Free Press.

Eurostat. 2016. "Fertility Indicators." Retrieved from: http://ec.europa.eu/eurostat/web/population-demography-migration-projections/birthsfertitily-data/database.

—. 2000. "Guidelines on Harmonised European Time Use Surveys." Available at: http://ec.europa.eu/eurostat/documents/3859598/5884753/KS-CC-04-007EN.PDF/03057369-0bfe-47d5-b584-be0868d65f29?version=1.0

Eyüboğlu, Ayşe, Şemsa Özar, and Hülya Tufan Tanrı̈öer. 2000. Socieconomic and Cultural Determinants of Urban Women's Labor Force Participation [Kentlerde Kadınların Işs Yaşamına Katılım Sorunlarının Sosyo-Ekonomik ve Kültürel Boyutları]. Ankara: TC Başbakanlık Kadının Statüsü ve Sorunları Genel Müdürlüğü.

Ferrant, Gaëlle, Luca Maria Pesando, and Keiko Nowacka. 2014. "Unpaid Care Work: The Missing Link in the Analysis of Gender Gaps in Labour Outcomes." OECD Development Centre Issues Paper 5. Available at: http://www.oecd.org/dev/development-gender/unpaid_care_work.pdf.

Floro, Maria Sagrario. 1995. “Women's Well-Being, Poverty, and Work Intensity.” Feminist Economics 1(3): 1-25.

Gustafsson, Siv S., Cécile MMP Wetzels, Jan Dirk Vlasblom, and Shirley Dex. 1996. “Women’s Labor Force Transitions in Connection with Childbirth: A Panel Data Comparison between Germany, Sweden and Great Britain." Journal of Population Economics 9(3): 223-46.

Hacettepe University Institute of Population Studies (HUIPS). 2008. Demographic and Health Survey. Ankara: Hacettepe University Institute of Population Studies. Available at: http://www.hips.hacettepe.edu.tr/eng/tdhs08/TDHS-2008_Main_Report.pdf

- 2013. Demographic and Health Survey. Ankara: Hacettepe University Institute of Population Studies. Available at: http://www.hips.hacettepe.edu.tr/eng/tdhs13/report/TDHS_2013_main.report.pdf

Hirway, Indira. 2009. Unpaid Work and the Economy: Gender, Time-Use and Poverty in Developing Countries. London: Palgrave Macmillan.

Hochschild, Arlie R., and Anne Machung. 1989. The Second Shift: Working Parents and the Revolution at Home. New York: Viking. 
Hurriyet Daily News. 2013. “Turkish PM Erdoğan Reiterates His Call for Three Children.” January 3. Retrieved from http://www.hurriyetdailynews.com/turkish-pm-erdogan-reiterates-hiscall-for-three-children.aspx?pageID $=238 \&$ nid $=38235$.

İlkkaracan, İpek. 2012. "Why so Few Women in the Labor Market in Turkey?" Feminist Economics 18(1): 1-37.
—. 2013. "The Purple Economy: A Call for a New Economic Order beyond the Green." In Genanet (ed.), Sustainable Economy and Green Growth: Who Cares? Berlin: Genanet. Available at: http://wedo.org/wp- content/uploads/2013/04/Int_WS_Sustainable_Economy_Green_Growth_who_cares_ EN.pdf

İlkkaracan, İpek, and Umut Gündüz. 2009. "Time-use, the Value of Non-Market Production and its Interactions with the Market Sector: The Case of Turkey." GDRI DREEM Working Paper. Paris: Groupe de recherche international: Développement des recherches. économiques euro-méditerranéennes.

Kasnakoğlu, Zehra, and Meltem Dayığlu. 2002. "Measuring the Value of Home Production in Turkey.” In Tuncer Bulutay (ed.), New Developments in National Accounts, Ankara: TurkStat.

Kasnakoğlu, Zehra, Meltem Dayığlu, and Erkan Erdil. 1996. "Time Use and Estimation of Value of Household Production.” METU Economic Research Center Working Paper, no. 7. Ankara: Middle East Technical University Economic Research Center.

Kaya Bahçe, Seçil A., and Emel Memiş. 2013. "Estimating the Impact of the 2008-09 Economic Crisis on Work Time in Turkey." Feminist Economics 19(3): 181-207.

Kızılırmak, Burça. 2008. "Labor Market Participation Decisions of Married Women: Evidence from Turkey." In Ashwini Deshpande (ed.), Globalization and Development: A Handbook of New Perspective. London: Oxford University Press.

Kızılırmak, Burça, and Emel Memiş. 2009. "The Unequal Burden of Poverty on Time Use." Levy Institute Working Paper No. 572. Annandale-on-Hudson, NY: Levy Economics Institute of Bard College. http://www.levyinstitute.org/publications/the-unequalburden-of-poverty-on-time-use.

Memiş, Emel, Umut Öneş, and A. Burça Kızılırmak. 2011. "Housewifisation of Women: Contextualising Gendered Patterns of Paid and Unpaid Work." In Saniye Dedeoglu and Adem Yavuz Elveren (eds), Gender and Society in Turkey: The Impact of Neoliberal Policies, Political Islam and EU Accession. London: IB Tairus.

Moghadam, Valentine M. 1998a. "Feminisms and Development." Gender \& History 10(3): 590-97. 
1998b. "The Feminization of Poverty in International Perspective." The Brown Journal of World Affairs 5(2): 225-49.

Öniş, Ziya. 2012. "The Triumph of Conservative Globalism: The Political Economy of the AKP Era." Turkish Studies 13(2): 135-52.

Organisation for Economic Co-operation and Development (OECD). 2016. OECD Employment Outlook 2016. Paris: OECD Publishing. Available at: http://www.oecd- ilibrary.org/employment/oecd-employment-outlook2016_empl_outlook-2016-en

Orloff, Ann Shola. 1993. "Gender and the Social Rights of Citizenship: State Policies and Gender Relations in Comparative Research.” American Sociological Review 58(3): 303-28.

Özar, Semsa, and Gulay Gunluk-Senesen. 1998. "Determinants of Female (Non-) Participation in the Urban Labour Force in Turkey.” METU Studies in Development 25(2): 311-28.

Özar, Şemsa, and Burcu Yakut-Cakar. 2013. "Unfolding the Invisibility of Women without Men in the Case of Turkey." Women's Studies International Forum 41: 24-34.

Özler, Şule. 2000. "Export Orientation and Female Share of Employment: Evidence from Turkey." World Development 28(7): 1239-48. doi:10.1016/S0305-750X(00)00034-6.

Rubery, Jill. 2013. "From 'Women and Recession' to 'Women and Austerity': A Framework for Analysis." In Maria Karamessini and Jill Rubery (eds.), Women and Austerity: The Economic Crisis and the Future for Gender Equality. London: Routledge.

Seguino, Stephanie. 2010. "Gender, Distribution, and Balance of Payments Constrained Growth in Developing Countries." Review of Political Economy 22(3): 373-404. doi:10.1080/09538259.2010.491285.

Turkish Labor Law. 2013a. "New Types of Parental Leave in Turkish Labor Law.” April 29. Retrieved from: http://turkishlaborlaw.com/news/legal-news/323-new-types-ofparental-levae-in-turkish-labor-law.

- 2013b. "Breastfeeding Break." October 7. Available at: http://turkishlaborlaw.com/news/business-in-turkey/338-breastfeeding-break.

- 2016. "Flexible Working after Child Birth and Adoption in Turkey." February 4. Available at: http://turkishlaborlaw.com/news/business-in-turkey/367flexible-working-after-childbirth-and-adoption-in-turkey.

Turkish Statistical Institute (TSI). 2016a. "Labor Force Statistics.” Retrieved from: http://www.turkstat.gov.tr/PreIstatistikTablo.do?istab_id=2262.

- 2016b. "Women in Statistics." Retrieved from http://www.turkstat.gov.tr/PreHaberBultenleri.do?id=21519 
Tuysuz, Gul. 2016. “7 Times Turkish President 'Mansplained' Womanhood.” CNN, June 9. http://www.cnn.com/2016/06/09/europe/erdogan-turkey-mansplained-womanhood/

United Nations Development Programme (UNDP). 2016. 2015 Human Development Report. New York: UNDP.

World Bank. n.d.a. DataBank. Retrieved from http://databank.worldbank.org/data/.

Zahidi, Saadia, and Herminia Ibarra. 2010. The Corporate Gender Gap Report 2010. Geneva, Switzerland: World Economic Forum. Available at:

http://www3.weforum.org/docs/WEF_GenderGap_CorporateReport_2010.pdf 